\title{
BRAVERY AS A VALUE IN THE HISTORY OF THE BULGARIAN LITERARY LANGUAGE
}

\section{VANYA MICHEVA}

INSTITUTE FOR BULGARIAN LANGUAGE, BULGARIAN ACADEMY OF SCIENCES v.micheva@gmail.com

The paper examines the semantic realizations and verbalizations of bravery as a value in the history of the Bulgarian language and culture. The author has studied linguistic data found in Old Bulgarian manuscripts from the $9^{\text {th }}-11^{\text {th }} \mathrm{c}$., original writings by Patriarch Euthymius from the $14^{\text {th }} \mathrm{c}$. and New Bulgarian damaskins from the $17^{\text {th }} \mathrm{c}$. The system of words and phrases that represent bravery as a value and its distribution in different cultural contexts are analyzed in relation to Christian ideas of the Middle Ages, Hesychasm and the new ideas of the pre-Revival period.

Keywords: history of Bulgarian language, Christian culture, verbal bravery, bravery of actions, bravery of martyrs

\section{REFERENCES}

BER 1 1971: Balgarski etimologichen rechnik [Bulgarian etymological dictionary]. T. 1 (1971). Sofia, AI „Prof. M. Drinov“.

BER 6 2002: Balgarski etimologichen rechnik [Bulgarian etymological dictionary]. T. 6 (2002). Sofia, AI „Prof. M. Drinov“.

Demina 1971: Demina, E. I. Tihonravovskii damaskin. Bolgarskii pamiatnik XVII veka [Tihonravov Damaskin. A Bulgarian Monument of the $17^{\text {th }}$ Century]. Chast' II. Sofia, Izdatelstvo na BAN.

Ivanova 1967: Ivanova, A. Troyanski damaskin. Balgarski pametnik ot XVII v. [Troyan Damaskin. A Bulgarian Monument of the $17^{\text {th }}$ Century]. Sofia, Izdatelstvo na BAN.

Kałužniacki 1901: Kałužniacki, E. Werke des Patriarchen von Bulgarien Euthymius (1375-1393) [The Writings of the Bulgarian Patriarch Euthymius]. Wien, Carl Gerold's sohn.,1901.

Keremidchieva 1992: Keremidchieva, Sl. Za narodnoto znachenie na dumata hrabar [On the Vernacular Meaning of the Word Brave]. - Paleobulgarica/Starobalgaristika, HVI, 1992, kn. 3, s. 87-90.

Micheva 2015: Micheva, $V$. Kartinata na sveta $\mathrm{v}$ ezika na novobalgarskite damaskini [The Picture of the World in the Language of the New Bulgarian Damaskins]. Sofia, DioMira.

Micheva 2016: Micheva, $V$. Svet i tma, svoe i chuzhoe v hristianskoi paradigme [Light and Dark, Own and Foreign Space in the Christian Paradigm]. Saarbrucken: LAP LAMBERT Academic publishing. 
Micheva 2006: Micheva, K. Konotatsiite na sveshtenoto [Connotations of the Sacred]. - Balgarski ezik, 2006, kn.1, s. 5-12.

Micheva-Peycheva 2016: Micheva-Peycheva, K. Sakral'ynaia chistota i profannaia nechistota [Sacral purity and profane impurity]. Saarbrücken, LAP LAMBERT Academic Publishing.

Micheva-Peycheva 2017: Micheva-Peycheva, K. Etnokulturnata binarnost v srednovekovnata balgarska literatura [Ethnocultural Binarity in Bulgarian Medieval Literature]. Sofia, DioMira.

Mladenova, Velcheva 2013: Mladenova, O., B. Velcheva. Loveshki damaskin. Novobalgarski pametnik ot XVII vek [The Lovech Damaskin. A New Bulgarian Monument of the $17^{\text {th }}$ Century]. Sofia, Natsionalna biblioteka „Sv. sv. Kiril i Metodiy".

RBE 1984: Rechnik na balgarskiya ezik [Dictionary of the Bulgarian Language]. T. 4. Sofia, Izdatelstvo na BAN.

RBE 1998: Rechnik na balgarskya ezik [Dictionary of the Bulgarian Language]. T. 9 (1998). Sofia, AI „Prof. M. Drinov“.

Rechnik 2012: Rechnik na knizhovniya balgarski ezik na narodna osnova ot XVII vek (varhu tekst na Tihonravoviya damaskin) [Dictionary of the Bulgarian Literary Language Based on the Vernacular of the $17^{\text {th }}$ Century (on Material from the Tihonravov Damaskin)]. Sofia, Izdatelstvo „Valentin Trayanov“.

RSBKE 1959: Rechnik na savremenniya balgarski knizhoven ezik [Dictionary of Contemporary Bulgarian Literary Language]. T. 3 (1959). Sofia, Izdatelstvo na BAN.

Starobalgarski rechnik I 1999: Starobalgarski rechnik [Dictionary of the Old Bulgarian Language]. T. I. Sofia, Izdatelstvo „Valentin Trayanov“.

Starobalgarski rechnik II 9: Starobalgarski rechnik [Dictionary of the Old Bulgarian Language]. T. II. Sofia, Izdatelstvo „Valentin Trayanov“.

Staroslavyanskii slovar' 1999: Staroslavyanskiy slovar [Dictionary of the Old Slavic Language]. Moskva, Russkii iazyk.

Tsibranska-Kostova 2011: Tsibranska-Kostova, M. Pokaynata knizhnina na Balgarskoto srednovekovie IX-XVIII v. (ezikovo-tekstologichni i kulturologichni aspekti) [Penitential Bulgarian Medieval Literature IX-XVIII c. (Linguistic, Textological and Culturological Aspects)]. Sofia, Izdatelstvo „Valentin Trayanov“.

$\triangle$ Assoc. Prof. Vanya Micheva, PhD Department of History of Bulgarian Language Institute for Bulgarian Language, Bulgarian Academy of Sciences 52 Shipchenski prohod, Bl. 17, 1113 Sofia, Bulgaria 